\title{
Pengembangan Model Pembelajaran Pendidikan Karakter Berbasis Media Sosial
}

\author{
Hengki Wijaya ${ }^{1)}$, Harmelia Tulak ${ }^{2)}$ \\ Sekolah Tinggi Filsafat Jaffray Makassar ${ }^{1)}$, Universitas Kristen Indonesia Toraja ${ }^{2)}$ \\ Jalan Gunung Merapi 103 Makassar ${ }^{1)}$ \\ 1)hengkilily1988@gmail.com, ${ }^{2)}$ tulakharmelia@gmail.com
}

(0411)-3624129

\begin{abstract}
Abstrak
Inovasi pembelajaran di era industri 4.0 menekankan pada penguatan karakter berbasis informasi teknologi. Revolusi pendidikan dapat terwujud ketika keterlibatan pendidik menjadi lebih rendah daripada keterlibatan peserta didik. Penggunaan media sosial yang tinggi di kalangan milenial memungkinkan untuk mewujudkan suatu model pembelajaran yang efektif, efisien, dan valid. Tulisan ini mengajukan suatu pemikiran untuk mengembangkan model pembelajaran pendidikan karakter berbasis media sosial untuk meningkatkan keterampilan kolaboratif pada pendidikan tinggi di Indonesia. Selain itu nilai-nilai karakter yang tertuang di dalamnya adalah kerja sama, tanggung jawab, kejujuran, dan kedisiplinan. Dalam tulisan ini akan menjelaskan grand theory, langkah-langkah model pembelajaran, dan model hipotetik pengembangan model pembelajaran pendidikan karakter berbasis media sosial. Tulisan ini adalah gagasan awal yang akan membantu dalam penelitian Research and Development dalam pengembangan model pembelajaran pendidikan karakter berbasis media sosial.
\end{abstract}

Kata Kunci: model, pembelajaran, pendidikan karakter, media sosial, sintaks, pendidikan

\section{PENDAHULAN}

Di era revolusi industri 4.0 memengaruhi pemahaman dunia pendidikan yang sudah terbiasa selama puluhan tahun dalam pembelajaran tatap muka yang kini dalam masyarakat heutagogy telah menyadari pentingnya aplikasi-aplikasi pembelajaran di luar kelas seperti pembelajaran online yang memungkinkan peserta didik untuk belajar sendiri, berkelompok, dan berkolaborasi dengan teman sebaya dan membuat komunitas atau kelompok belajar. Hal ini dimungkinkan dengan tersedianya internet dengan kecepatan yang memadai untuk mengakses aplikasi, dan media sosial.

Aplikasi pembelajaran yang dengan kemudahan akses dengan biaya murah akan "mematikan" tempat les, bimbingan belajar, dan pertemuan dengan dosen atau pendidik menjadi hal yang membosankan. Berdasarkan data statistik pengguna media sosial di dalamnya adalah juga termasuk pengguna aplikasi maka diperoleh data pengguna Facebook didominasi golongan usia 1824 tahun dengan persentase 20,4 persennya adalah wanita dan 24,2 persennya adalah pria (Pertiwi, 2018; Kemp, 2018). Data ini mengingatkan bahwa usia 18-24 adalah usia produktif. Mobilisasi yang cepat terjadi karena adanya kemudahan, dan praktis untuk digunakan oleh pendidik, dan peserta didik. Selain itu, peserta didik lebih mudah memahami sesuatu apabila pesan, atau teori itu disampaikan dengan audio visual yang dapat tersimpan, dan dapat terus-menerus dilakukan pengulangan apabila peserta didik belum memahaminya.

Instruksi Presiden Republik Indonesia, Bapak Joko Widodo yang menyatakan Indonesia harus siap "Revolusi Mental" di era disrupsi, yaitu perubahan mendasar hingga akarnya bagi generasi bangsa ini terutama dengan penguatan pendidikan karakter di berbagai aspek kehidupan sepanjang hayat. Perpres No. 87 Tahun 2017 tentang Penguatan Pendidikan Karakter yang ditindaklanjuti dengan Keputusan Menteri Pendidikan dan Kebudayaan Republik Indonesia Nomor 20 Tahun 2018 tentang Penguatan Pendidikan Karakter pada satuan pendidikan formal. Hal ini berarti pemerintah memberikan penguatan kepada pentingnya pendidikan karakter di institusi pendidikan tanpa terkecuali. Oleh karena itu, penulis berpendapat bahwa penguatan karakter hanya bisa dilakukan secara cepat apabila didukung dengan sarana yang dapat berbagi (share) dengan sesama secara cepat, dan efektif. Salah satu sarana itu adalah melalui media sosial.

Penelitian Mar'ati (2014) di pesantren, menunjukkan beberapa nilai-nilai yang dapat ditemukan adalah sikap hormat, persaudaraan, keikhlasan dan kesederhanaan, kemandirian, larangan melanggar aturan, dan keteladanan. Lain 
halnya data mahasiswa Sekolah Tinggi Filsafat Jaffray yang diobservasi menunjukkan sikap hormat, persaudaraan, menghargai perbedaan, teladan, tanggung jawab, kerendahan hati, disiplin, dan kerja keras. Nilai-nilai karakter ini perlu ditingkatkan karena "penularan" sikap yang buruk dari angkatan mahasiswa sebelumnya kepada angkatan mahasiswa baru.

Penelitian lainnya yang dilakukan oleh Palila (2015), menunjukkan bahwa ada tiga karakter pokok yang dibutuhkan oleh mahasiswa Program Studi Psikologi Fishum UIN Sunan Kalijaga Yogyakarta, yaitu kegigihan, regulasi diri, dan empati. Selanjutnya dijelaskan disiplin, proaktif, tanggung jawab, konsisten, dan antusias, optimis, percaya diri, tangguh, tabah, dan berpikir positif, kerja sama, menghargai dan menghormati orang lain, mendengarkan dan memahami orang lain adalah turunan karakter dari ketiga hal tersebut di atas.

\subsection{Pendidikan Karakter}

Lickona (1991:29; Elkind dan Sweet, 2004) mengatakan bahwa pendidikan karakter adalah upaya yang disengaja untuk membantu orang memahami, peduli, dan bertindak berdasarkan nilai-nilai etika." Selain itu, ia mengungkapkan bahwa "pendidikan karakter adalah upaya yang disengaja untuk menumbuhkan kebajikan yaitu kualitas manusia yang objektif secara objektif yang mana baik untuk orang itu dan baik untuk seluruh masyarakat." Dalam konteks pendidikan, Mulyasa berpendapat (2016: 9) bahwa tujuan pendidikan karakter adalah untuk meningkatkan kualitas proses dan hasil pendidikan. Dengan demikian pendidikan karakter adalah suatu proses yang disadari, dan sengaja dilakukan untuk menerapkan perilaku kebajikan bagi dirinya sendiri, dan bagi orang lain.

Pendidikan karakter harus melibatkan metode, teknik, dan materi untuk membuat anakanak tidak memiliki alasan atau menginginkan kebaikan didahului oleh pengetahuan nilai kebaikan, sehingga mereka mengembangkan sikap untuk mencintai yang baik seperti kasih sayang, dan akhirnya mereka bersedia melakukan perbuatan baik (Lickona, 1991). Oleh karena itu, sebuah model pembelajaran dibutuhkan untuk mencapai tujuan nilai-nilai karakter.

\subsection{Model Pembelajaran Pendidikan Karakter Berbasis Media Sosial}

Menurut Mulyasa (2016:165), Model pembelajaran pendidikan karakter dilakukan dengan berbagai model yaitu: 1) pembiasaan dan keteladanan; 2) CTL (Contextual Teaching and Learning); 3) bermain peran (role playing); 4) pembelajaran partisipasif (participative instruction). Dari keempat model tersebut penulis berfokus kepada Contextual Teaching and Learning (CTL).

Hudson dan Whisler (2008:54) mendefinisikan Contextual Teaching and Learning (CTL) sebagai cara untuk memperkenalkan konten menggunakan berbagai teknik pembelajaran aktif yang dirancang untuk membantu siswa menghubungkan apa yang sudah mereka ketahui dengan apa yang diharapkan untuk mereka pelajari, dan untuk membangun pengetahuan baru dari analisis dan sintesis dari proses pembelajaran ini.

Pembelajaran pendidikan karakter melalui model CTL yang dapat digunakan untuk mengefektifkan dan menyukseskan pendidikan karakter di sekolah (Mulyasa, 2016:174). Lebih lanjut Mulyasa (2016) menjelaskan bahwa CTL adalah model pembelajaran berkarakter, karena dalam pelaksanaannya lebih menekankan pada keterkaitan antara materi pembelajaran dengan kehidupan peserta didik sehingga dapat mempraktikkan karakter yang dipelajari dalam kehidupan sehari-hari.

Menurut (Johnson, 2002), CTL dianggap sebagai sistem yang komprehensif. CTL terdiri dari beberapa bagian yang terhubung satu sama lain. Jika bagian-bagian ini terkait dengan satu sama lain, maka akan menghasilkan efek yang melebihi hasil yang diberikan pada bagian-bagiannya secara terpisah. Sistem CTL mencakup delapan komponen, yaitu:

1. Menciptakan hubungan yang bermakna (Making meaningful connections);

2. Melakukan pekerjaan yang berarti (doing significant work);

3. Melakukan pembelajaran mandiri (self regulated learning);

4. Melakukan kerja sama (collaborating);

5. Melakukan pemikiran kritis dan kreatif;

6. Membantu individu untuk tumbuh dan berkembang;

7. Mencapai standar yang tinggi;

8. Menggunakan penilaian autentik.

Cara efektif untuk menghubungkan pembelajaran dengan konteks kehidupan sehari-hari. Mulyasa (2016), mengungkapkan ada enam metode berikut ini. 
1. Menghubungkan pembahasan konsep nilainilai inti etika sebagai landasan karakter dengan keseharian peserta didik;

2. Memasukkan materi dari bidang lain di dalam kelas;

3. Dalam mata pelajaran yang tetap terpisah terdapat topik-topik yang saling berhubungan;

4. Mata pelajaran gabungan yang menyatukan isu-isu moral;

5. Menggabungkan sekolah dan pekerjaan;

6. Penerapan nilai-nilai moral yang dipelajari di sekolah ke masyarakat.

Model pembelajaran pendidikan karakter ini pada perguruan tinggi dapat dilakukan pada mata kuliah yang multidisiplin ilmu seperti psikologi, ilmu pengetahuan dan teknologi, kewirausahaan dan lainnya di mana di dalam mata kuliah itu dapat dimasukkan nilai-nilai karakter. Nilai-nilai karakter ini dapat dibagikan melalui media sosial, dan sumbel belajar yang terupdate bersumber dari media sosial. Oleh karena itu, penulis berusaha untuk mengembangkan model pembelajaran pendidikan karakter berbasis media sosial.

\subsection{Pendidikan Karakter Berbasis Media Sosial}

Mengapa menggunakan media sosial? Media sosial sudah menjadi sarana untuk belajar dan proses pembelajaran di kelas dan di luar kelas karena media sosial sudah menjadi tren bagi generasi milenial. Sobaih et al., (2016:303) bahwa meningkatnya penggunaan media sosial oleh mahasiswa digital di pendidikan tinggi membutuhkan lebih banyak perhatian dari para peneliti dan pembuat kebijakan. Dosen sangat sadar akan media sosial dan menggunakannya secara teratur dalam kehidupan pribadi mereka. Mereka juga melihat nilai besar menggunakan media sosial untuk tujuan yang berhubungan dengan akademis tetapi penggunaan aktual mereka untuk mengajar dan belajar adalah pada tingkat minimal. Banyak dosen tidak mengetahui alat media sosial yang lebih tepat untuk mengajar dan belajar, misalnya Blog dan Wiki dan kegunaan alat media sosial lainnya, misalnya Facebook atau WhatsApp.

Romero (2015) mengemukakan "Media sosial memiliki potensi untuk meningkatkan pembelajaran siswa, memfasilitasi interaksi pendidik dan interaksi perserta didik, pengembangan keterampilan dan tingkat kepuasan dengan keterlibatan pembelajaran mobile yang baru." Sobaih et al. (2016) mengatakan "Media sosial dapat menjadi platform yang tepat untuk menjembatani kesenjangan digital antara negara maju dan berkembang dan juga antara lembaga dan peserta didik digital mereka dalam konteks negara berkembang.” Al-Rahmi et al. (2015) menyimpulkan: "Media sosial dapat membantu dalam meningkatkan kinerja akademik mahasiswa dan peneliti ketika dosen dan pengawas mengintegrasikan media sosial dalam metode pembelajaran mereka. Temuan menunjukkan bahwa media sosial memfasilitasi pembelajaran kolaboratif dan keterlibatan mahasiswa dan ini meningkatkan kinerja akademik mahasiswa dan peneliti." Dengan demikian media sosial sangat bermanfaat untuk membagikan nilai-nilai karakter dengan mengintegrasikan media sosial ke dalam model pembelajaran.

Pembelajaran mandiri dan berkelompok berbasis media sosial akan mewujudkan ciri-ciri kemampuan untuk mereflesikan pembelajaran, keterampilan komunikasi dan kerja sama dalam kelompok, kreativitas probadi dan kelompok dan memberikan dampak nilai positif secara pribadi dan dalam kelompok.

Dalam penelitian Balakrishnan \& Lay (2015) tentang gaya belajar siswa dan dampaknya pada penggunaan media sosial dalam pembelajaran yang digambarkan pada gambar 1 .

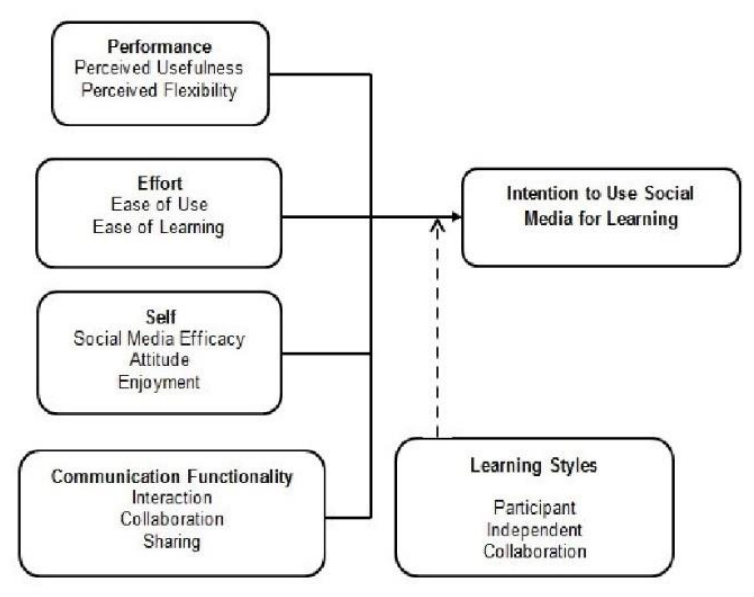

Gambar 1. Dampak Gaya Belajar Siswa Pada Pengunaan Media Sosial Dalam Pembelajaran

Media sosial dapat mendorong pembelajaran karena popularitas media sosial dan yang meluas untuk pembuatan kelompok studi online, mendukung berbagi ide, berbagi dan mempromosikan interaksi aktif di antara mahasiswa dan dosen yang dapat mempermudah dan mendorong pembelajaran (Balakrishnan \& Lay, 2015). Selanjutnya Balakrishnan \& Lay (2015) mengungkapkan bahwa media sosial harus diintegrasikan ke dalam bagian kurikulum 
pengajaran dan pembelajaran pendidikan tinggi harus dilakukan hanya setelah melakukan analisis yang mendalam dan menyeluruh di mana adanya pedoman yang jelas berkaitan dengan penggunaan alat tersebut harus disediakan untuk keduanya yaitu dosen dan mahasiswa. Kegiatan pembelajaran yang dirancang oleh pendidik dan difasilitasi melalui media sosial harus didasarkan pada teori pedagogi, pembelajaran pedagogi yang sehat untuk membangkitkan minat dan pengalaman belajar peserta didik.

Permasalahan yang akan dijawab dalam tulisan ini adalah: 1) menganalisis kebutuhan mahasiswa akan pendidikan karakter dalam rangka mewujudkan penguatan pendidikan karakter yang dominan pada mahasiswa dengan menampilkannya di dalam kelas melalui proses pembelajaran pendidikan karakter. Untuk mempercepat penangkapan informasi oleh mahasiswa maka cara yang tepat adalah melalui pembuatan video yang akan dibagikan melalui media sosial seperti WhatApps, Instagram, YouTube, Facebook dan media sosial lainnya; 2) kajian teori yang sesuai dengan topik permaslaahan; 3) menentukan metodologi penelitian yang digunakan; 4) menentukan model hipotetik penelitian.

\section{METODE}

Metode yang digunakan dalam penelitian ini menggunakan pendekatan Research and Development (R\&D). Model pengembangan yang digunakan adalah Model 4D (Define, Design, Develop, dan Disseminate) oleh Thiagarajan, Semmel, dan Semmel (1974) yang dikombinasikan dengan Model Jolly \& Bolitho. Langkah-langkah penelitian di atas dengan teori pengembangan 4D (Define, Design, Develop, Disseminate) dari S. Thiagarajan. Pada tahap definisi terdiri atas 1) tahap studi pendahuluan dan analisis kebutuhan berbasis pendidikan karakter; 2) Pada tahap kedua desain terdiri atas draft model yang didasarkan pada penelitan pendahuluan, uji kepatutan modal, dan model hipotetik. 3) Pada tahap pengembangan model, Validasi model oleh ahli (valid), Pengujian Model (kepraktisan dan keefektivan), Model akhir; 4) Desiminasi model secara terbatas.

Pada penelitian pendahuluan (define) bertujuan untuk menganalisis kebutuhan mahasiswa akan pentingnya pengembangan model pembelajaran pendidikan karakter berbasis media sosial. Pada tahap define dalam prosedur penelitian dilakukan dengan secara kualitatif melalui observasi, kajian teori, wawancara, dan Focused Group
Discussion (FGD) dengan 58 mahasiswa angkatan 2017 dalam mata kuliah psikologi umum dan dua dosen serta Ketua Prodi Pendidikan Agama Kristen dan Ketua Prodi Teologi.

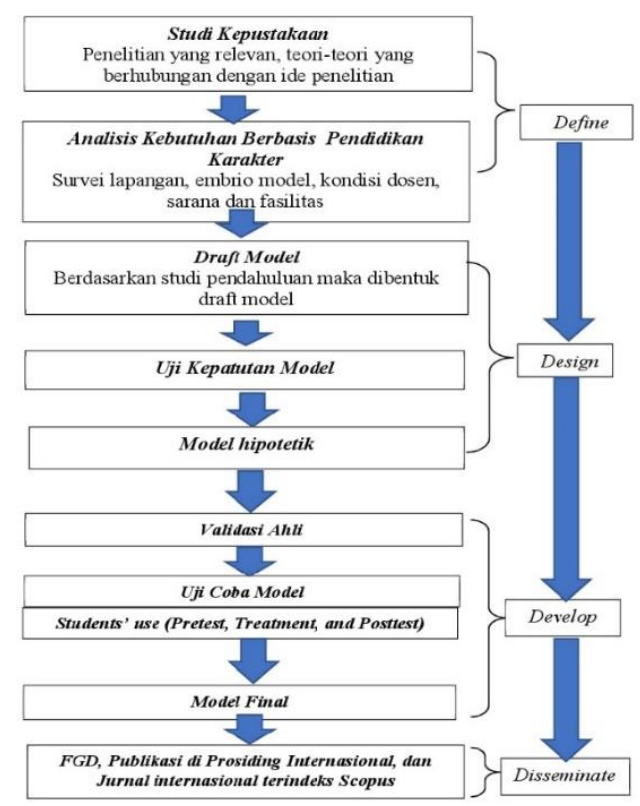

Gambar 2. Prosedur Penelitian Research \& Development

\subsection{Model Hipotetik}

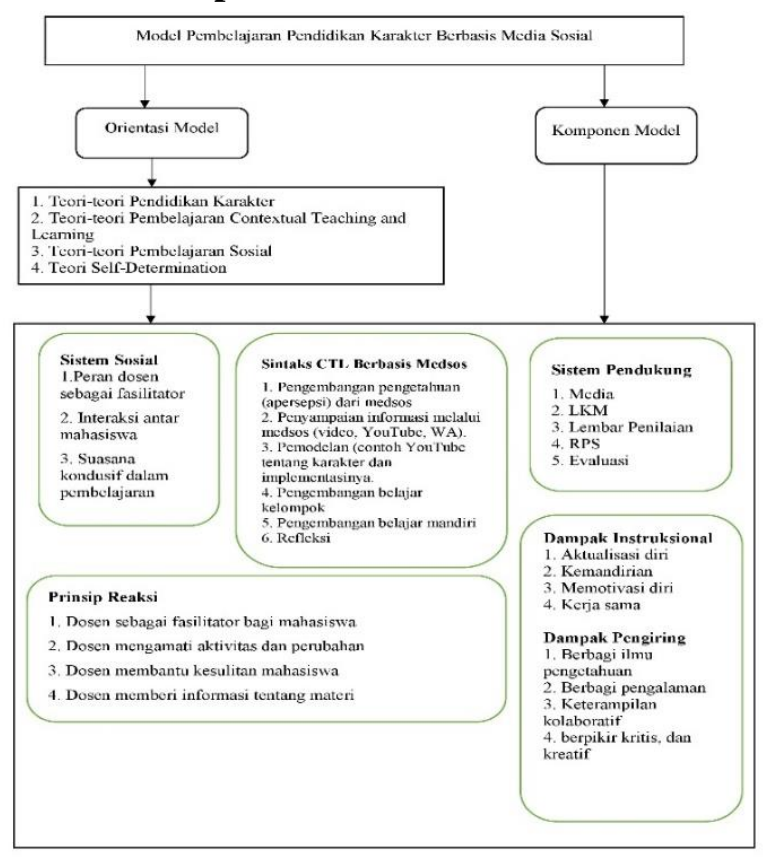

Gambar 3. Model Hipotetik Model Pembelajaran Pendidikan Karakter Berbasis Media Sosial

\subsection{Langkah-langkah Pengembangan Model}

Menurut Jolly dan Bolitho dalam Tomlinson (1998) ada beberapa langkah pengembangan dalam model ini, yaitu: 
1. Identifikasi kebutuhan model pembelajaran (Identification of need for materials)

Identifikasi kebutuhan mahasiswa akan pengembangan model pembelajaran pendidikan karakter berbasis media sosial dengan menggunakan angket kepada dosen dan mahasiswa. Pada tahap ini akan diteliti pada mahasiswa apakah model pembelajaran yang ada saat ini memiliki muatan pendidikan karakter?

2. Eksplorasi kebutuhan (Exploration of need)

Eksplorasi kebutuhan model merujuk pada silabus, RPS, bahan ajar, LKM mata kuliah Psikologi Umum khususnya pada bahasan persepsi dan sensasi. Diskusi kelompok terarah (FGD) dilakukan dengan panduan atau pedoman umum, mencantumkan isu-isu yang ingin diketahui tanpa menentukan secara kaku urutan pertanyaannya. Seluruh proses diskusi kelompok terarah dengan informan didokumentasikan dengan recorder.

3. Realisasi kontekstual (Contextual realization of models)

Pada analisis konteks ini dilakukan penyebaran angket kuesioner kepada mahasiswa untuk melihat apakah kebutuhan mahasiswa akan pendidikan karakter saat ini sudah terpenuhi dengan model pembelajaran saat ini yang disampaikan dosen termasuk pemahaman mahasiswa akan pentingnya pendidikan karakter di perguruan tinggi.

4. Realisasi pedagogik (Pedagogical Realization of models)

Pada tahap ini, peneliti mencari bentuk-bentuk tugas dan latihan yang disesuaikan dengan kebutuhan mahasiswa dalam pendidikan karakter dengan subbahasan pada mata kuliah psikologi umum.

5. Produksi Model (Production of models)

Pada tahap ini, peneliti memproduksi produk yang masih berupa prototipe awal. Hal-hal yang perlu diperhatikan dalam langkah ini adalah menentukan desain produk, lay out, jenis huruf, reproduksi produk, dan lain-lain.

6. Penggunaan model pembelajaran oleh dosen (Students' use of model)

7. Evaluasi model pembelajaran yang mengacu pada tujuan khusus yang ingin dicapai (Evaluation of models against agreed objectives). Model yang digunakan dalam kegiatan belajar mengajar dievaluasi dengan mencocokkan kembali dengan tujuan pembelajaran.

\section{HASIL DAN PEMBAHASAN}

Berdasarkan wawancara dan Focused Group Discussion (FGD) dengan 68 mahasiswa angkatan
2017 dalam mata kuliah psikologi umum dan dua dosen serta Ketua Prodi Pendidikan Agama Kristen dan Ketua Prodi Teologi. Data yang diperoleh dalam penelitian ini dianalisis melalui beberapa tahap yaitu organisasi data, reduksi data ke dalam satuan-satuan analisis, koding, pengujian terhadap dugaan, dan interpretasi. Data ini untuk menemukan karakter dominan yang perlu dikembangkan sesuai dengan kurikulum institusi dan kebutuhan karakter yang perlu ditingkatkan pada mahasiswa.

Melalui observasi dalam grup psikologi A dan B didapati mahasiswa sebanyak 17 mahasiswa yang tidak memiliki aplikasi WhatsApp. Terdapat $25 \%$ yang tidak memiliki aplikasi WA (WhatsApp) dari jumlah 68 mahasiswa yang mengambil mata kuliah psikologi umum.

\subsection{Tahap Define: Analisis Kebutuhan}

Peneliti melakukan analisis terhadap beberapa referensi yang digunakan oleh dosen dalam mengajar Mata Kuliah Psikologi Umum khususnya pada sub bahasan Persepsi dan Sensasi. Berdasarkan kajian referensi beberapa buku psikologi umum didapati bahwa teori-teori psikologi memungkinkan nilai-nilai karakter diajarkan melalui pemahaman (understanding) psikologi yang bertujuan untuk mengubah tingkah laku melalui proses pembelajaran. Penekanan pembelajaran di dalam kelas seharusnya tidak menekankan aspek kognitif saja, melainkan secara keseluruhan. Pemahaman yang benar tentang karakter didukung oleh sensasi yang diterima dari indra mata, telinga, dan indra lainnya. Media sosial hadir untuk memberi penguatan sensasi, dan cara belajar yang kreatif melalui audio-visual yang berbunyi, terlihat, dan bersuara.

Proses pembelajaran masih menggunakan metode ceramah dan diskusi kelompok serta presentasi kelas terbukti membosankan. Penulis menyimpulkan bahwa mahasiswa menginginkan suasana pembelajaran yang berbeda dari yang biasanya. Sementara dalam diskusi kelompok hanya beberapa mahasiswa yang terlibat dalam diskusi maka perlu adanya suatu model pembelajaran yang bertujuan menanamkan nilainilai karakter pada diri mahasiswa secara menyeluruh (kognitif, afektif, dan psikomotorik).

Kebutuhan mahasiswa untuk pendidikan karakter dipahami oleh mahasiswa sebagai penerapan nilai-nilai luhur bangsa dan secara mendasar adalah nilai-nilai agama yang diyakini. Mahasiswa juga memahami bahwa penerapan nilai-nilai karakter tersebut dinilai masih rendah dalam proses pembelajaran, sementara himbauan dan dorongan dosen lebih banyak ditekankan pada 
saat ibadah dan pertemuan-pertemuan di luar kelas untuk meningkatkan ketakwaan kepada Tuhan. Secara khusus dalam memenuhi kebutuhan mahasiswa dalam pembinaan karakter sebagai sekolah tinggi yang menghasilkan luaran yang memiliki karakter yang baik dan benar.

Berdasarkan kuesioner yang diberikan kepada mahasiswa angkatan 2017 maka diperoleh bahwa karakter yang perlu ditingkatkan adalah kerja keras, kerja sama, kedisiplinan, tanggung jawab, dan kejujuran adalah karakter yang dominan yang skalanya masih rendah. Penilaian tertinggi pada angka 5 dan penilaian terendah pada skala angka 1. Secara lengkap dapat dilihat pada tabel 1 di bawah ini.

Tabel 1. Pretest Karakter Mahasiswa Angkatan 2017

\begin{tabular}{clcc}
\hline No & \multirow{2}{*}{ Aspek } & \multicolumn{2}{c}{ Rerata Pretest } \\
\cline { 3 - 4 } & & Kelompok & Mandiri \\
\hline 1 & Kerja keras & 3,5 & 2,8 \\
2 & Kerja sama & 3,2 & 2,5 \\
3 & Disiplin & 3,0 & 2,2 \\
4 & Tanggung & 2,8 & 2,5 \\
& Jawab & & \\
5 & Kejujuran & 2,6 & 2,4 \\
\hline
\end{tabular}

\subsection{Komponen Model Pembelajaran Pendidikan Karakter Berbasis Media Sosial}

Komponen model pembelajaran pendidikan karakter berbasis media sosial mengacu kepada komponen model yang dikemukakan oleh Joyce dkk. (2011) yaitu sintaks, sistem sosial, sistem pendukung, prinsip reaksi, dampak instruksional dan dampak pengiring adalah sebagai berikut.

\subsection{Sintaks}

Sintaks adalah urutan kegiatan atau juga yang disebut fase. Sintaks model pembelajaran pendidikan karakter berbasis media sosial terdiri atas enam fase yaitu:

Tabel 2. Sintaks Model Pembelajaran Pendidikan Karakter Berbasis Media Sosial (Modifikasi dari Mulyasa, 2016).

\begin{tabular}{|c|l|l|}
\hline Fase & \multicolumn{1}{|c|}{ Indikator } & Tingkah laku Dosen \\
\hline 1 & $\begin{array}{l}\text { Menyampaikan } \\
\text { tujuan dan } \\
\text { memotivasi } \\
\text { siswa dengan } \\
\text { pengembangan } \\
\text { pengetahuan }\end{array}$ & $\begin{array}{l}\text { 1. Dosen menggali } \\
\text { pengetahuan awal } \\
\text { mahasiswa } \\
\text { mengenai materi } \\
\text { mata kuliah }\end{array}$ \\
& $\begin{array}{l}\text { 2. Dosen menjelaskan } \\
\text { kompetensi dan }\end{array}$ \\
\hline
\end{tabular}

\begin{tabular}{|c|c|c|}
\hline & & $\begin{array}{l}\text { karakter yang } \\
\text { dibentukserta } \\
\text { kegunaannya dalam } \\
\text { kehidupan dengan } \\
\text { menggunakan media } \\
\text { sosial (Video, } \\
\text { YouTube) } \\
\text { 3. Dosen } \\
\text { mengelompokkan } \\
\text { dengan mahasiswa } \\
\text { dalam kelompok } \\
\text { dengan jumlah 3-5 } \\
\text { orang }\end{array}$ \\
\hline 2 & $\begin{array}{l}\text { Menyampaikan } \\
\text { informasi } \\
\text { berbasis media } \\
\text { sosial }\end{array}$ & $\begin{array}{l}\text { Dosen menyampaikan } \\
\text { informasi tentang garis } \\
\text { besar materi } \\
\text { pembelajaran kepada } \\
\text { mahasiswa dengan } \\
\text { media sosial. }\end{array}$ \\
\hline 3 & $\begin{array}{l}\text { Pemberian } \\
\text { pemodelan }\end{array}$ & $\begin{array}{l}\text { Dosen mengajak } \\
\text { mahasiswa mengamati } \\
\text { contoh model yang } \\
\text { ditampilkan melalui } \\
\text { video. }\end{array}$ \\
\hline 4 & $\begin{array}{l}\text { Pengembangan } \\
\text { belajar } \\
\text { kelompok }\end{array}$ & $\begin{array}{l}\text { 1. Dosen membimbing } \\
\text { kelompok-kelompok } \\
\text { belajar untuk } \\
\text { mendiskusikan, dan } \\
\text { mengerjakan tugas } \\
\text { pembuatan video } \\
\text { tentang karakter dari } \\
\text { pemodelan yang ada. } \\
\text { 2. Mahasiswa } \\
\text { memikirkan konsep } \\
\text { dan ide untuk } \\
\text { membuat pemodelan } \\
\text { yang melahirkan ide } \\
\text { kreativitas, dan } \\
\text { pemikiran kritis. }\end{array}$ \\
\hline 5 & $\begin{array}{l}\text { Pengembangan } \\
\text { belajar mandiri }\end{array}$ & $\begin{array}{l}\text { Mahasiswa } \\
\text { mengembangkan } \\
\text { modelnya sesuai dengan } \\
\text { aturan dan tujuan yang } \\
\text { sudah disusun } \\
\text { sebelumnya. }\end{array}$ \\
\hline 6 & Refleksi & $\begin{array}{l}\text { Dosen bersama } \\
\text { mahasiswa mereflesikan } \\
\text { apa yang telah } \\
\text { dipelajari, kesulitan } \\
\text { yang dihadapi, dan } \\
\text { persepsi dari sensasi } \\
\text { yang telah dilakukan. } \\
\text { Dosen menjelaskan } \\
\text { tugas lanjutan untuk } \\
\text { melaksanakan konsep } \\
\text { dan ide selanjutnya. }\end{array}$ \\
\hline
\end{tabular}


Keenam fase ini dituangankan dalam

langkah-langkah kegiatan yaitu:

1. Kegiatan awal yang terdiri atas fase 1 dan 2 di mana dosen memberikan salam pembuka, berdoa, mengecek kesiapan mahasiswa, aperspesi, menyampaikan motivasi dan tujuan pembelajaran yang harus dicapai mahasiswa dan dosen menyampaikan informasi berkenaan dengan materi perkuliahaan sebelum melangkah pada kegiatan inti. Kegiatan ini sebelumnya sudah ada apersepsi melalui media sosial, dan penayangan video pendek. Dosen membuat kelompok dan mahasiswa masuk ke dalam kelompok berjumlah 3-5 orang secara merata dan memberikan tugas yang akan didiskusikan dalam kelompok.

2. Kegiatan Inti yang terdiri atas fase 3, 4, dan 5 di mana mahasiswa mengamati model materi berbentuk video. Mahasiswa mendiskusikan dalam kelompok. Materi dan referensi tersebut bersumber dari media sosial misalnya blog, website, jurnal online, YouTube, WhatsApp, Intagram, Facebook dan sejemnisnya. Mahasiswa bersama dalam kelompok dan setiap kelompok diberikan lembar kerja elektronik untuk mengerjakan tugas sesuai dengan materi yang dipelajari dan dikerjakan secara kelompok. Selanjutnya mahasiswa mengerjakan secara mandiri ide dan gagasan kritis terhadap video yang diamati dan menyusun suatu gagasan baru yang akan disajikan dalam bentuk video dan penjelasan.

3. Kegiatan penutup terdiri atas fase 6 di mana mahasiswa bersama dosen membuat refleksi atas apa yang telah dipelajari dalam materi perkuliahan ini dan membuat suatu pernyataan refleksi yang dibagikan melalui media sosial. Dosen juga menyampaikan pertemuan selanjutnya apa yang perlu diketahui oleh mahasiswa. Dosen dapat meminta mahasiswa menutup proses pembelajaran dengan doa. Dosen menyampaikan salam kepada mahasiswa.

\subsection{Sistem Sosial}

Peran dosen dalam memfasilitasi mahasiswa dalam pemberian materi dan lembar kerja mahasiswa (LKM). Dosen berinteraksi dengan mahasiswa. Mahasiswa menggali informasi lebih mendalam tentang materi berbasis multikultural dan kecerdasan emosional. Suasana kondusif dan menyenangkan terjadi dalam kelas karena proses peningkatan kecerdasan emosional berjalan secara alamiah, tanpa paksaan.

\subsection{Sistem Pendukung}

Sistem pendukung terdiri atas materi pelajaran yang diberikan kepada mahasiswa. Lembar Kerja Mahasiswa (LKM) diberikan kepada mahasiswa untuk dikerjakan dalam kelompok dan secara individu. Lembar pengamatan mahasiswa (angket) juga dibutuhkan dalam mendukung model pembelajaran ini. Angket berbentuk Google Form atau sejenisnya yang dapat diakses dengan link pada perangkat media sosial.

\subsection{Prinsip Reaksi}

a. Dosen memfasilitasi mahasiswa dalam meningkatkan keterampilan kolaboratif

b. Dosen mengamati aktivitas dan perubahan sosial mahasiswa sebagaimana yang ditampilkan dalam Lembaran Kerja Mahasiswa.

c. Dosen membantu mahasiswa dengan cara mendampingi jika ada mahasiswa yang kesulitan dalam proses peningkatan keterampilan kolaboratif.

d. Dosen membantu mahasiswa memperoleh informasi yang lebih luas tentang bagaimana meningkatkan keterampilan kolaboratif melalui model pembelajaran berbasis media sosial.

\subsection{Aplikasi}

Model pembelajaran pendidikan karakter berbasis media sosial dapat diplikasikan dengan tujuan meningkatkan keterampilan mahasiswa dalam hubungannya dengan teman sebaya dan meningkatkan kemampuan penggunaan Informasi Teknologi dalam hal ini media sosial dengan terlibat dalam pembuatan video dan mempresentasikannya di hadapan mahasiswa lainnya. Selain itu model ini juga dapat mengevaluasi kemampuan mahasiswa dalam berpendapat melalui presentasi kelompoknya.

\subsection{Dampak Instruksional dan Dampak Pengiring}

Dampak intruksional model pembelajaran karakter berbasis media sosial terdiri atas:

a) aktualisasi diri mahasiswa dalam kelompok berbasis media sosial;

b) kemandirian dalam belajar di media sosial secara positif dan berbagi ilmu dan pengalaman;

c) memotivasi diri untuk bekerja dan belajar dan mengembangkan keterampilan kolaboratif bersama teman kelompok dan teman sebaya melalui media sosial;

d) membina hubungan dengan orang lain dengan mempraktikkan pendidikan karakter dalam 
komunitas media sosial untuk mencapai tujuan pembelajaran yaitu penguatan karakter.

\subsection{Dampak Instruksional dan Dampak Pengiring}

Dampak intruksional model pembelajaran pendidikan karakter berbasis media sosial terdiri atas:

a) Aktualisasi diri mahasiswa yang memiliki karakter bangsa dalam kelompok berbasis media sosial;

b) Kemandirian dalam belajar dalam media sosial secara positif dan berbagi ilmu dan pengalaman yang menunjukkan karakter bangsa;

c) Memotivasi diri untuk bekerja dan belajar dan mengembangkan keterampilan kolaboratif bersama teman kelompok dan teman sebaya melalui media sosial yang mencerminkan karakter bangsa;

d) Membina hubungan dengan orang lain yang berbeda dalam komunitas media sosial untuk mencapai tujuan pembelajaran pendidikan karakter.

Dampak pengiring model pembelajaran kooperatif berbasis media sosial adalah:

a) berbagi ilmu pengetahuan melalui kerja sama, kreativitas dan inovasi dalam bermedia sosial;

b) berbagi pengalaman dalam kelompok dan teman sebaya dengan cara menggali potensi diri dengan teman sebaya untuk meningkatkan kerja keras, kerja sama, kedisiplinan, tanggung jawab, dan kejujuran;

c) dapat belajar keterampilan-keterampilan kolaboratif dalam kelompok. Saling berbagi dalam kelompok melalui media sosial dan tatap muka di kelas maupun di luar kelas.

\section{KESIMPULAN}

Berdasarkan analisis kebutuhan mahasiswa akan pengembangan model pendidikan karakter melalui wawancara dan Focus Group Discussion (FGD) maka diperoleh beberap karakter yang dominan untuk ditingkatkan yaitu karakter kerja keras, kerja sama, disiplin, tanggung jawab, dan kejujuran. Untuk mempercepat pemahaman, dan tindakan yang berkarakter pada mahasiswa maka pembelajaran perlu berbasis media sosial. Media sosial bukan hanya sarana melainkan proses kehidupan masyarakat milineal di mana pengetahuan, kreativitas, dan berpikir kritis ada tersedia di dalam media sosial.
Topik bahasan sensasi dan persepsi dalam mata kuliah psikologi umum akan menjadi berbeda bila pengembangan modelnya berbasis media sosial. Melalui langkah-langkah pembelajaran Contextual Teaching and Learning berasis media sosial dapat meningkatkan aspek karakter dan menjadi teladan karakter bagi diri sendiri, kelompok, dan masyarakat.

Tahap pendefinisian, model hipotetik yang dihasilkan dapat ditindaklanjuti dengan tahap disain dimana model ini akan diuji validasinya oleh ahli, serta keefektifan, dan kepraktisan oleh dosen dan pengguna dalam hal ini mahasiswa.

\section{UCAPAN TERIMA KASIH}

Ucapan terima kasih disampaikan sebesarbesarnya kepada institusi Sekolah Tinggi Filsafat Jaffray dan Makassar berkerja sama dengan dosen Universitas Kristen Indonesia Toraja sebagai bentuk kerja sama kolaboratif untuk kedua institusi ini.

\section{DAFTAR PUSTAKA}

Balakrishnan, V., \& Lay, Gan Chin. (2015). Students' Learning Styles and Their Effects on the Use of Social Media Technology for Learning. Telematics and Informatics. http://dx.doi.org/10.1016/j.tele.2015.12.004

Elkind, D dan Sweet, F. (2004). Building Character in Schools: Practical Ways to Bring Moral Instruction to Life. San Francisco: Jossey Bass.

Hudson, Clemente C., Whisler, Vesta R. (2008). Contextual Teaching and Learning for Practitioners. Systemics, Cybernetics And Informatics 6 (4): 54-58.

Johnson, E. B. (2002). Contextual teaching and learning: What it is and why it's here to stay. Newbury Park, CA: Corwin Press.

Jolly, D. and Bolitho, R. (1998). "A Framework for Materials Writing.” In: Tomlinson, B., Ed., Materials Development in Language Teaching. Cambridge University Press, Cambridge, 90115.

Kemp, S. (2018). Digital in 2018: World's internet users pass the 4 billion mark - We Are Social. Diakses 27 Juli 2018. https://wearesocial.com/blog/2018/01/globaldigital-report-2018.

Lickona, T. (1991). Education for Character; How Our Schools Can Teach Respect and Responsibility. New York: Bantam Books. 
Mar'ati, Rela. (2014). Pesantren Sebagai Basis Pendidikan Karakter; Tinjauan Psikologis. $\mathrm{Al}$ Murabbi 1 (1): 1-15.

Mulyasa, E. (2016). Manajemen Pendidikan Karakter. Jakarta: Bumi Aksara.

Palila, Sara. (2015). Analisis Kebutuhan Karakter Mahasiswa Psikologi Fakultas Ilmu Sosial Dan Humaniora UIN Sunan Kalijaga Yogyakarta. Humanitas 12 (2): 105-117.

Pertiwi, W. K. (2018). Riset Ungkap Pola Pemakaian Medsos Orang Indonesia. Diakses 27 Juli 2018. https://tekno.kompas.com/read/2018/03/01/103 40027/riset-ungkap-pola-pemakaian-medsosorang-indonesia.

Romero, O. C. (2015). Social Media as learning tool in higher education: the case of Mexico and South Korea. Sinéctica, Revista Electrónica de Educación, 44, 1-15.

Sobaih, A. E. E., Moustafa, M. A., Ghandforoush, P., \& Khan, M. (2016). To use or not to use? Social media in higher education in developing countries. Computers in Human Behavior, 58, 296-305. https://doi.org/10.1016/j.chb.2016.01.002

Thiagarajan, S., Semmel, D. S., Semmel M. I. (1974). Instructional Development for Training Teacher for Exceptional Children. Indiana: Indiana University Bloomington.

Wijaya, H. Arismunandar. "Pengembangan Model Pembelajaran Kooperatif Tipe STAD Berbasis Media Sosial." Jurnal Jaffray 16, no. 2 (Oktober 2018): 175-176.

Wijaya, Hengki. Analisis Data Kualitatif Ilmu Pendidikan Teologi. Makassar: Sekolah Tinggi Theologia Jaffray, 2018. 